plerixafor can be used to treat mobilization failure and is usually well tolerated $[6,7]$. The only option upon stem cell mobilization failure with G-CSF is bone marrow harvesting. Our donor was given plerixafor "just in time"; he had an active infection and did not consent to bone marrow harvesting. While plerixafor is usually used for mobilization in lymphoma or myeloma patients, literature data are available about its use in allogeneic settings [8]. Stem cells in numbers adequate for safe transplantation were collected in a single procedure.

This report indicates that influenza A may suppress the hematopoietic system, negatively affecting stem cell mobilization. The problem may be overcome by plerixafor administration.

Keywords: Plerixafor, Influenza A, Healthy donor

Anahtar Sözcükler: Plerixafor, İnfluenza A, Sağlıklı verici

Conflict of Interest: The authors of this paper have no conflicts of interest, including specific financial interests, relationships, and/or affiliations relevant to the subject matter or materials included.

\section{References}

1. Eyre TA, King AJ, Peniket A, Rocha V, Collins GP, Pawson R. Partial engraftment following plerixafor rescue after failed sibling donor peripheral blood stem cell harvest. Transfusion 2014;54:1231-1234.

2. Gattillo S, Marktel S, Rizzo L, Malato S, Malabarba L, Coppola M, Assanelli A, Milani R, De Freitas T, Corti C, Bellio L, Ciceri F. Plerixafor on demand in ten healthy family donors as a rescue strategy to achieve an adequate graft for stem cell transplantation. Transfusion 2015;55:1993-2000.

3. Hölig K. G-CSF in healthy allogeneic stem cell donors. Transfus Med Hemother 2013;40:225-235.

4. Rohn A, Kessler HH, Valentin T, Linkesch W, Neumeister P. Prophylactic oseltamivir treatment for prevention of donor-recipient influenza $A$ H1N1 virus transmission does not compromise stem cell mobilization or engraftment. Bone Marrow Transplant 2011;46:312-313.

5. Teijaro JR, Walsh $\mathrm{KB}$, Rice $\mathrm{S}$, Rosen $\mathrm{H}$, Oldstone MB. Mapping the innate signaling cascade essential for cytokine storm during influenza virus infection. Proc Natl Acad Sci U S A 2014;111:3799-3804.

6. Hauge AW, Haastrup EK, Sengeløv H, Minulescu L, Dickmeiss E, FischerNielsen A. Addition of plerixafor for CD34+ cell mobilization in six healthy stem cell donors ensured satisfactory grafts for transplantation. Transfusion 2014;54:1055-1058.

7. Flomenberg N, Devine SM, Dipersio JF, Liesveld JL, McCarty JM, Rowley SD, Vesole DH, Badel K, Calandra G. The use of AMD3100 plus G-CSF for autologous hematopoietic progenitor cell mobilization is superior to G-CSF alone. Blood 2005;106:1867-1874.

8. Namdaroglu S, Korkmaz S, Altuntas F. Management of mobilization failure in 2017. Transfus Apher Sci 2017;56:836-844.

\title{
Influenza A Infection and Stem Cell Mobilization
}

\section{Influenza A Enfeksiyonu ve Kök Hücre Mobilizasyonu}

\author{
(D) Sora Yasri ${ }^{1}$, (D) Viroj Wiwanitkit ${ }^{2}$ \\ ${ }^{1}$ KMT Primary Care Center, Bangkok, Thailand \\ ${ }^{2}$ Hainan Medical University, Department of Tropical Medicine, Haikou, Hainan, China
}

To the Editor,

We read the publication entitled "Use of Plerixafor to Mobilize a Healthy Donor Infected with Influenza $A$ " and found it to be very interesting [1]. Yeral et al. [1] mentioned that "The effects of influenza $A$ infection on stem cell mobilization are not known" and concluded that "This report indicates that influenza A may suppress the hematopoietic system, negatively affecting stem cell mobilization. The problem may be overcome by plerixafor administration" [1]. This article may provide a new observation and confirm the usefulness of plerixafor in achieving stem cell mobilization. Nevertheless, it should be noted that this is not the first case of stem cell transplantation in which the donor has influenza $A$ infection. Lee et al. [2] reported stem cell transplantation from a related donor infected with influenza H1N1 2009 and in that case the transplantation was completely done without noting any problem of stem cell mobilization due to the influenza virus. Regardless of using plerixafor, however, stem cell transplantation in cases in which the donor has influenza infection is a considerable challenge and it is questionable whether the procedure should be done then or not. 
Keywords: Influenza, Infection, Stem cell

Anahtar Sözcükler: İnfluenza, Enfeksiyon, Kök hücre

Conflict of Interest: The authors of this paper have no conflicts of interest, including specific financial interests, relationships, and/or affiliations relevant to the subject matter or materials included.

\section{References}

1. Yeral $M$, Aytan $P$, Boğa $C$. Use of plerixafor to mobilize a healthy donor infected with influenza A. Turk J Hematol 2018;35:139-140.

2. Lee SH, Cheuh H, Yoo KH, Kim YJ, Sung KW, Koo HH, Kim DH, Kim SJ, Kim K,

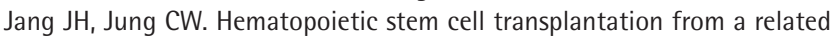
donor infected with influenza H1N1 2009. Transpl Infect Dis 2011;13:548550 .

\section{Reply to the Authors:}

\section{To the Editor,}

We read the recent letter by Yasri and Wiwanitkit [1] regarding our manuscript with great interest. We are pleased with their contributions and comments. The literature data with regard to the effect of influenza A on hematopoietic cell mobilization is limited to only several case reports $[2,3]$.

However it would not be incorrect to relate mobilization failure to Influenza in a donor who has no prior diseases, who is not using any kind of medication or substance, and who is considered to be healthy in clinical and laboratory evaluations before mobilization. Mobilization failure may be associated with cytokine increase, presence of viremia and viral titers. Lee et al. [2] reported three donors who were infected with influenza. Mobilization was postponed for a short period of time in one donor due to poor mobilization risk. Two donors could be mobilized with granulocyte-colony stimulating factor. Nevertheless one of the donors could not be regarded as good mobilized. Because despite two days of apheresis procedure, the collected CD34+ cells from the healthy donor were $\leq 2 \times 106 / \mathrm{kg}$.

With our case we aimed to point out that influenza A may affect mobilization negatively and this condition may be overcome with plerixafor. It should be known that mortality is inevitable in a patient who received myeloablative conditioning regimen without stem cells.

Best Regards

Mahmut Yeral, Pelin Aytan, Can Boğa

\section{References}

1. Yasri S, Wiwanitkit V. Influenza A Infection and Stem Cell Mobilization, Turk J Hematol 2018;35:137-153.

2. Lee SH, Cheuh H, Yoo KH, Kim YJ, Sung KW, Koo HH, Kim DH, Kim SJ, Kim K, Jang JH, Jung CW. Hematopoietic stem cell transplantation from a related donor infected with influenza H1N1 2009. Transpl Infect Dis 2011;13:548-550.

3. Rohn A, Kessler HH, Valentin T, Linkesch W, Neumeister P. Prophylactic oseltamivir treatment for prevention of donor-recipient influenza A H1N1 virus transmission does not compromise stem cell mobilization or engraftment. Bone Marrow Transplant. 2011;46:312-313. 